\title{
RESPONSE OF GROWTH, YIELD ATTRIBUTES AND YIELD TO THE APPLICATION OF KNAP AND NAA IN COWPEA (VIGNA UNGUICULATA (L.) WALP.)
}

\author{
Md. Jafar Ullah", Quazi Abdul Fattah ${ }^{1}$ and Feroza Hossain ${ }^{2}$ \\ Department of Agronomy, Sher-e-Bangla Agricultural University, Dhaka-1207, Bangladesh
}

Key words: Cowpea, Vigna unguiculata, Plant height, Dry matter, Yield

\begin{abstract}
Six concentrations each of KNap and NAA along with a control were tested on cowpea cv. Bari Falon2. Results showed that irrespective of treatment differences, dry matter of cowpea (Vigna unguiculata) increased during 60 to 105 DAS. Concentrations above 50 ppm NAA increased plant height. The dry matter and yield increased with the increasing of the concentrations of KNap and NAA up to 1250 and 50 ppm, respectively. No significant differences of dry matter accumulation, grain yield and almost all the yield attributes were observed in between $1250 \mathrm{ppm}$ KNap and $50 \mathrm{ppm}$ NAA. The highest values of dry matter/plant $(54.52 \mathrm{~g})$, pod length $(13.15 \mathrm{~cm})$, number of pods/plant $(10.29)$, number of seeds/pod $(10.61)$, 1000 seed weight $(122 \mathrm{~g})$, seed yield/plant $(15.51 \mathrm{~g})$, seed yield/ha $(1630 \mathrm{~kg})$ and harvest index $(37.32 \%)$ were obtained due to application of $1250 \mathrm{ppm}$ KNap. Yield attributes had significantly positive correlation amongst them.
\end{abstract}

\section{Introduction}

With the advent of wheat, boro and maize cultivation and rice in Bangladesh, the area and production of pulse crops have been gradually decreasing (BBS 2004) and as a result, there is deficit of pulse grains in Bangladesh. Thus, it is necessary to increase the productivity of pulse crops in terms of grain yield per unit area.

Cowpea is one of the pulse crops with proteinaceous seeds. Although suitable to grow at all regions of Bangladesh, it is extensively grown in the southern part in the rice-based cropping systems after the harvest of transplant aman rice (Rahman 1989). To increase the yield productivity of cowpea, various agronomic techniques have been tried by many workers (Biswas et al. 1996, Sarker 1994). However, its productivity needs to be further increased so that its cultivation becomes profitable.

Productivity of some pulse crops has been found to be increased by the use of different growth regulators. Among them KNap and NAA were used in some field crops (Fattah and Wort 1970, Hossain 1976, Jahan 2001, Kalita et al. 1995, Karim 2005). However, published reports of the effect of these two growth regulators on the productivity of cowpea are scanty. The present investigation was, therefore, undertaken to study the effect of KNap and NAA on the growth, yield attributes and yield of cowpea.

\section{Materials and Methods}

The experiment was carried out at Sher-e-Bangla Agricultural University Farm, Sher-eBangla Nagar, Dhaka during the rabi season of 1999-2000. BARI Falon-2 was grown under irrigated conditions. Six concentrations of KNap, namely 750(T1), 1000(T2), 1250(T3), 1500(T4), 1750(T5) and 2000(T6) ppm and six concentrations of NAA, namely, 10(T7), 30(T8), 50(T9), 70(T10), 90(T11) and 110(T12) ppm along with a control (T0) were tested. The experiment was laid out in a randomized complete block design with three replications for each treatment.

*Corresponding author. E-mail: jafarullah58@yahoo.co.uk, ${ }^{1}$ Department of Botany, University of Dhaka, Dhaka-1000, Bangladesh. ${ }^{2}$ Department of Botany, Jahangirnagar University, Savar, Dhaka, Bangladesh. 
The unit plot size was $5 \mathrm{~m} \times 4 \mathrm{~m}$. The land was opened by a disc plough and then prepared by three subsequent ploughing with a country plough. At the final land preparation, nitrogen, phosphorus, potassium, boron, sulfur and zinc at the rate of $20 \mathrm{~kg} \mathrm{~N}, 50 \mathrm{~kg} \mathrm{P}_{2} \mathrm{O}_{5}, 40 \mathrm{~kg} \mathrm{~K}_{2} \mathrm{O}, 0.60$ $\mathrm{kg} \mathrm{B}, 18.0 \mathrm{~kg} \mathrm{~S}$ and $2 \mathrm{~kg} \mathrm{Zn}$ per hectare were applied in the form of urea, triple super phosphate, muriate of potash, borax, gypsum and zinc sulfate fertilizers, respectively.

Seeds were sown on November 15, 1999 maintaining row to row distance and a plant to plant distance of 50 and $20 \mathrm{~cm}$ respectively. The depth of sowing seeds was $2-3 \mathrm{~cm}$. Growth regulators were sprayed on the aerial parts of plants at 45 days after sowing (DAS) till drip.

Ten plants from each plot were randomly selected and data on plant height and total dry matter were taken at 60, 75, 90 and 105 DAS at the onset of branching, onset of flowering, pod formation and maturity stages respectively. Data on pod length was taken at 75, 90 and 105 DAS. At the harvest, number of pods/plant, number of seeds/pod and 1000 seed weight were taken. Data on yield/ha and harvest index were taken from the samples which were harvested at maturity from the pre-demarcated area of each plot. Data were statistically analyzed and means were compared by LSD at $5 \%$ level of significance.

\section{Results and Discussion}

Results presented in Fig.1 showed that the plant height increased with the increase of age. It further increased due to the application of both KNap and NAA. However, increasing the concentration over $1250 \mathrm{ppm}$ of KNap (T3) and $70 \mathrm{ppm}$ of NAA (T10), the plant height decreased. The highest plant height was exhibited by T10 which, however was not significantly higher than those of T4 - T6 (1500 - 2000 KNap) and T9 (50 NAA). The control showed significantly lower plant height at all growth stages except at 60 DAS.

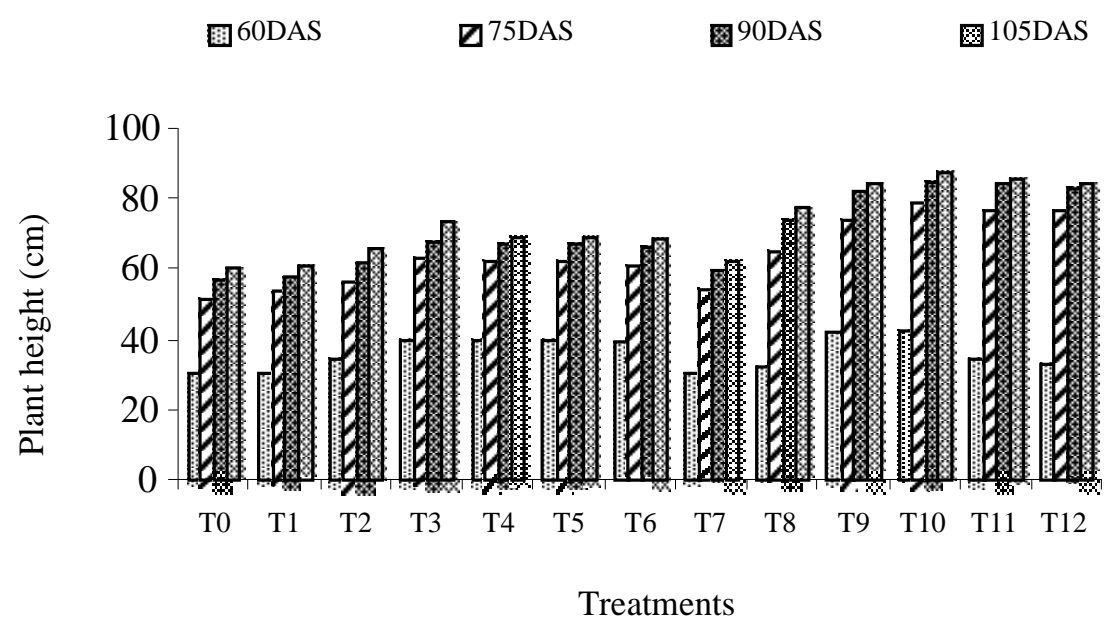

Fig. 1. Effect of growth regulators on plant height $(\mathrm{cm})$ of cowpea cv. Barifalon -2 (Vigna unguiculata (L.) Walp.) at different growth stages.

The positive effect of KNap on plant height of cowpea is in conformity with the report in bushbean (Fattah and Wort 1970). The lengthening effect of NAA on many grain legume crops was also reported earlier (Uddin et al. 1994, Maske et al. 1997). The increase in plant height due to the application of growth regulators have been attributed to the acceleration of cell division and elongation of internodes (Brian and Hemming 1958). The increase in plant height could also be either due to the increase in the number of cells or due to increase in size of cells or due to both (Mallik and Fattah 1974). 
Weight of total dry matter (dm) continued to increase from 60 to 105 DAS (Fig. 2). Results showed that at all the growth stages, T3 showed the highest and T9 showed the next highest $\mathrm{dm}$. But there was no significant difference between T3 and T9. Most of other treatments had significantly lower values than T3 and T9. Such findings revealing the significant effect of KNap on the total dry matter accumulation fully agree with the reports of Fattah and Wort (1970) and Karim (2005). There is also evidence that NAA had positive effect on the dry matter accumulation in black gram (Saxena 1994, Patel and Saxena 1994), green gram (Kalita et al. 1995) and chickpeas (Karim 2005).

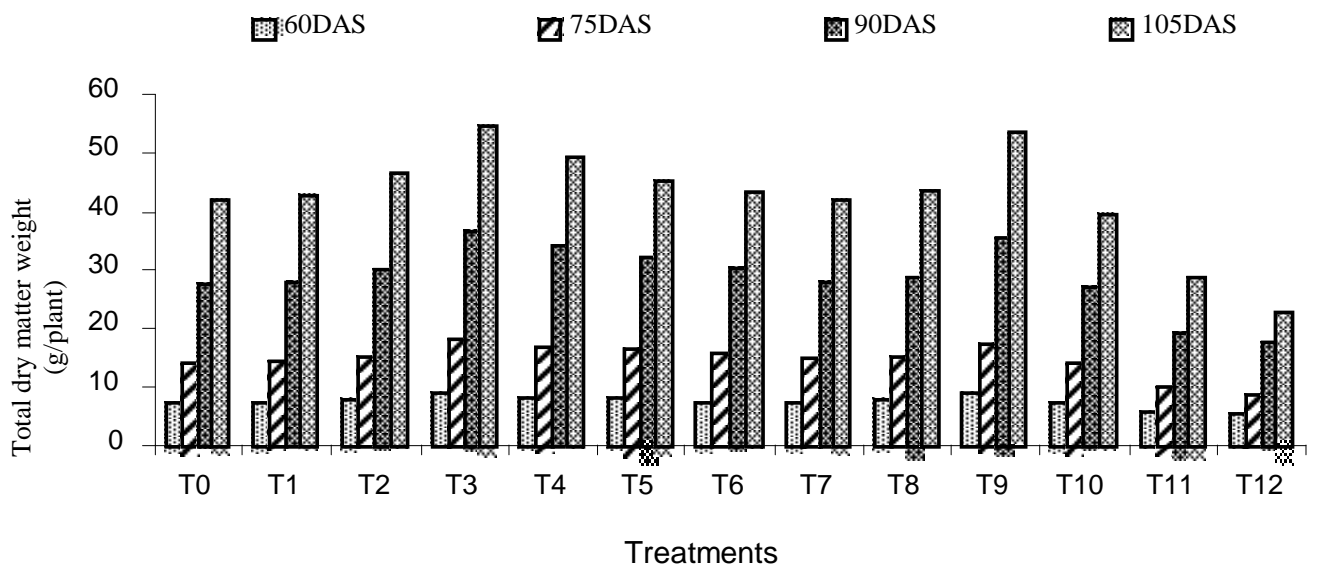

Fig. 2 Effect of growth regulators on total dry matter weight (g/plant) of cowpea cv. Barifalon -2

(Vigna unguiculata (L.) Walp.) at different growth stages.

It was observed that the growth regulators at higher concentrations showed decreased dry matter and yield, which could be attributed to the inhibition in metabolic pathways (Siddiqui and Krishnamoorthy 1991). However, the real cause behind this could be explained if quantitative and qualitative analysis of some important enzymes involved in different metabolic pathways could have been monitored periodically during the different growth phases of the crop (Fattah and Wort 1970).

Pod length ranged from $0.00-4.93,9.25-12.34$ and $9.54-13.15 \mathrm{~cm}$ at 75, 90 and 105 DAS, respectively (Fig. 3). This corroborates with the findings of Naidu et al. (1996) and BARI (1988). Treatments had significant effect on pod length at all the growth stages. At 75 DAS, T11 and T12 did not have any pods. At 90 DAS, T3, T4, T5 and T9 produced pods which were statistically similar but significantly longer than those of other treatments. Likewise, at 105 DAS, T3, T9 and T10 had similar but significantly higher pod length than that of other treatments.

Data on number of pods/plant, number of seeds/pod, 1000 seed weight, yield/plant, yield/ha and harvest index is presented in Table 1. Results showed that number of pods varied between 3.62 and 11.98 which agree with the findings of Naidu et al. (1996), BARI (1988) and Taslima (2003). The highest number of pods (11.98) were shown by T3 although this was not significantly higher than those of T4 and T9.

The positive effect of KNap on the increase in the number of pods in bushbean (Fattah and Wort 1970), soybean (Hossain 1976) and chickpeas (Karim 2005) has been previously reported. NAA was also found to be effective in increasing the number of pods in cowpea (Deshai and Deore 1985), lablab bean (Uddin et al. 1994), pigeonpea (Rao and Narayan 1998) and chickpeas (Karim 2005). 
The highest number of seeds was due to $\mathrm{T} 3$ which, however, was not significantly higher than those of T4 and T9. The control had lower value, but that was higher than those of T10, T11 and T12. In mustard, it was also found that the KNap had an effect on the production of seeds/pod (Khanom 1992). Deshai and Deore (1985) and Karim (2005) obtained increased number of seeds/pod in pulses due to application of NAA.

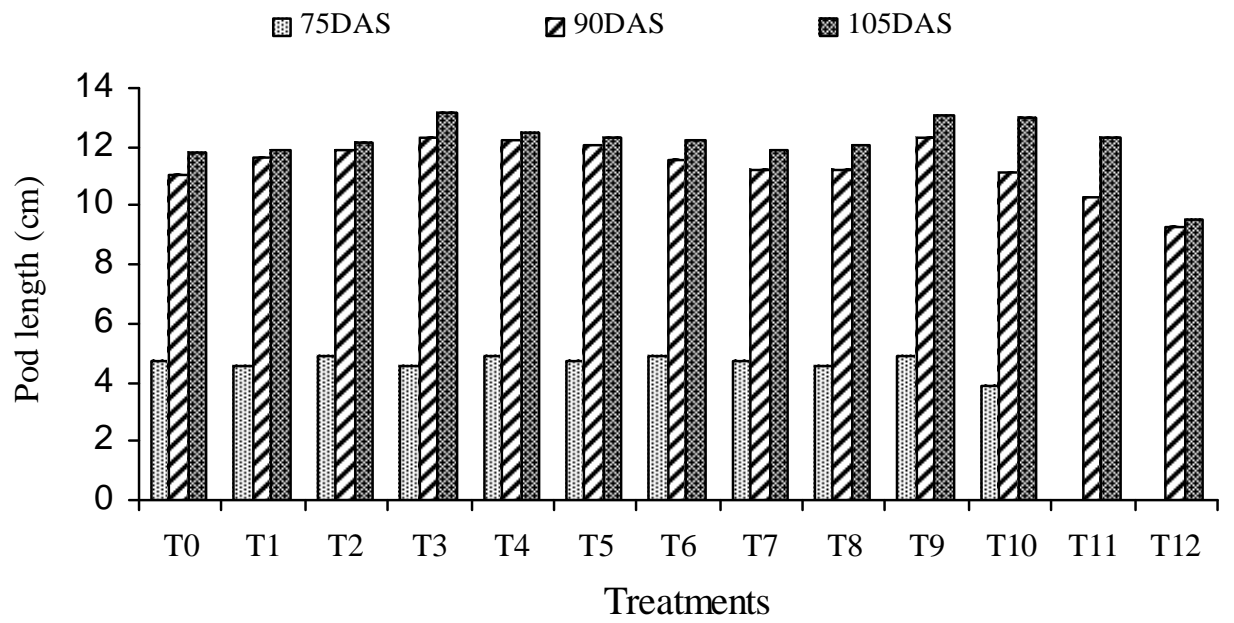

Fig. 3. Effect of growth regulators on pod length $(\mathrm{cm})$ of cowpea $\mathrm{cv}$. Barifalon -2 (Vigna unguiculata (L.) Walp.) at different growth stages during.

1000 seed weight ranged from $90-122 \mathrm{~g}$. Among all the treatments, the highest and the lowest 1000 seed weight was shown by $\mathrm{T} 3$ and T12, respectively. There was no significant difference among T3, T4 and T9. 1000 seed weight decreased drastically at the concentrations of T11 and T12. The positive effect of KNap on 1000 seed weight has been reported in soybean (Khan 1973) and chickpea (Karim 2005). NAA had also been found to increase the 1000 seed weight in pea (Singh et al. 1972).

Table 1. Effect of growth regulators on yield and yield attributes of cowpea cv. Barifalon -2 (Vigna unguiculata (L.) Walp.).

\begin{tabular}{llccccc}
\hline Treatment & $\begin{array}{l}\text { Number of } \\
\text { pods/ plant }\end{array}$ & $\begin{array}{c}\text { Number of } \\
\text { seeds/ pod }\end{array}$ & $\begin{array}{c}1000 \text { seed } \\
\text { weight }(\mathrm{g})\end{array}$ & $\begin{array}{c}\text { Seed yield/ } \\
\text { plant }(\mathrm{g})\end{array}$ & $\begin{array}{c}\text { Seed yield/ha } \\
(\mathrm{kg})\end{array}$ & $\begin{array}{c}\text { Harvest } \\
\text { index }(\%)\end{array}$ \\
\hline T0 & 9.62 & 10.24 & 114 & 11.23 & 1216 & 27.03 \\
T1 & 9.71 & 10.45 & 115 & 11.67 & 1232 & 28.08 \\
T2 & 10.29 & 10.61 & 117 & 12.77 & 1349 & 30.74 \\
T3 & 11.98 & 10.61 & 122 & 15.51 & 1630 & 37.32 \\
T4 & 11.11 & 10.11 & 119 & 13.37 & 1395 & 32.17 \\
T5 & 10.52 & 10.01 & 113 & 11.90 & 1238 & 28.64 \\
T6 & 10.01 & 9.92 & 113 & 11.22 & 1173 & 27.00 \\
T7 & 9.92 & 10.24 & 114 & 11.58 & 1223 & 27.87 \\
T8 & 10.02 & 10.35 & 117 & 12.13 & 1277 & 29.20 \\
T9 & 11.95 & 10.60 & 119 & 15.07 & 1600 & 36.28 \\
T10 & 8.57 & 10.21 & 114 & 9.98 & 1050 & 24.01 \\
T11 & 5.47 & 9.50 & 100 & 5.20 & 548 & 12.51 \\
T12 & 3.62 & 7.36 & 90 & 2.40 & 250 & 5.77 \\
LSD $(\mathbf{0 . 0 5})$ & $\mathbf{1 . 0 5}$ & $\mathbf{0 . 1 4}$ & $\mathbf{3 . 1 0}$ & $\mathbf{1 . 4 5}$ & $\mathbf{1 6 2}$ & $\mathbf{1 . 5 8}$ \\
CV $(\%)$ & 6.29 & 0.80 & 1.54 & 7.35 & 7.77 & 6.23 \\
\hline
\end{tabular}


Yield/plant ranged from $2.40-15.51 \mathrm{~g}$. Treatment T3 showed the highest yield, while T12 the lowest. There was no significant difference among T3 and T9 in this respect. The control showed lower value than all treatments except T10, T11 and T12. Increase in yield/plant due to the application of NAA has also been reported by Karim (2005) in chickpea.

The yield/ha was found in between 250 and $1630 \mathrm{~kg}$. Among all the treatments, the highest yield was found with T3 while the lowest with T12. There was no significant difference between $\mathrm{T} 3$ and $\mathrm{T} 9$ in this respect. The control showed lower values than $\mathrm{T} 1$ and $\mathrm{T} 9$, but higher values than those of T10, T11 and T12.

Harvest index (HI) ranged between 5.77 and $37.32 \%$. Treatment T3 showed the highest HI. However, this was not significantly different from T9. The HI decreased drastically at the higher KNap concentrations, T5 and T6. It also decreased more drastically at the higher concentrations of NAA over $50 \mathrm{ppm}$. There is evidence that KNap increased the HI of rice (Jahan 2001). Harvest index of legumes has also been reported to be increased due to the application of NAA (Uddin et al. 1994, Rao and Narayanan 1998, Karim 2005).

Correlation analyses among the yield components are presented in Table 2. It can be seen from the Table 2 that there was a significant positive correlation among all the yield components.

Table 2. Correlation analysis among different yield components of cowpea cv. Barifalon-2 (Vigna unguiculata (L.) Walp.).

\begin{tabular}{lccccc}
\hline $\begin{array}{l}\text { No. pods/ } \\
\text { plant }\end{array}$ & $\begin{array}{c}\text { No. seeds/ } \\
\text { pod }\end{array}$ & $\begin{array}{c}1000 \text { seed } \\
\text { weight }\end{array}$ & $\begin{array}{c}\text { Seed } \\
\text { weight/plant }\end{array}$ & $\begin{array}{c}\text { Seed } \\
\text { yield/ha }\end{array}$ & $\begin{array}{c}\text { Harvest } \\
\text { index }\end{array}$ \\
\hline No. pods/plant & $0.87^{*}$ & $0.97^{*}$ & $0.99 *$ & $0.99^{*}$ & $0.94^{*}$ \\
No. seeds/pod & & $0.93^{*}$ & $0.88^{*}$ & $0.88^{*}$ & $0.95^{*}$ \\
1000 seed weight & & & $0.98^{*}$ & $0.98^{*}$ & $0.97^{*}$ \\
Seed weight/plant & & & $1.00^{*}$ & $0.94^{*}$ \\
Seed yield/ha & & & & $0.94^{*}$ \\
\hline
\end{tabular}

* Significant at $5 \%$ level.

Among the treatments, T3 1250 ppm KNap showed the highest values of dry matter, pod length, number of pods/plant, number of seeds/pod, 1000 seed weight, seed yield/plant, seed yield/ha and harvest index.

\section{References}

BARI (Bangladesh Agricultural Research Institute). 1988. Annual Report for 1986-1987. BARI, Joydebpur, Gazipur, Bangladesh.

BBS (Bangladesh Bureau of Statistics). 2004. Statistical Year Book of Bangladesh. Bangladesh Bureau of Statistics, Planning Division, Ministry of Planning, Government of the People's Republic of Bangladesh.

Biswas, P.K., J.U. Ahmed, R.R. Saha and G.S. Torofder. 1996. Response of different nitrogen levels on nodulation, dry matter and seed yield in cowpea genotypes. Bangladesh J. Agril. Res. 21(1): 75-79.

Brian, P.W. and H.G. Hemming. 1958. Complementary action of gibberellic acid and auxins in pea internode extension. Ann. Bot. 22: 1-17.

Deshai, S.N. and D.D. Deore. 1985. Influence of growth regulators on the seed production of cowpea. J. Maharastra Agri, Univ. 10(1): 89-90.

Fattah, Q.A. and D.J. Wort. 1970. Metabolic responses of bushbean plants to naphthenate applicaftion. Canad. J. Bot. 48: 861-866.

Hossain, S.F. 1976. Effect of KNap and TIBA on physiology of soybean plants. M.Sc. Thesis. Department of Botany, Dhaka University, Dhaka-1000, Bangladesh. 
Jahan, N. 2001. Effect of naphthenate on fertilizer use efficiency, physiological and biological responses of rice plants. Ph. D.Thesis. Department of Botany, Dhaka University, Dhaka-1000, Bangladesh.

Kalita, P., S.C. Dey and K. Chandra. 1995. Influence of foliar application of phosphorus and naphthalene acetic acid on nitrogen, dry matter accumulation and yield of green gram. Indian J. Pl. Physiol. 38(3): 197-202.

Karim, M.F. 2005. Physiological and biochemical responses of chickpea (Cicer arietenum L.) following application of fertilizers and growth regulators. Ph. D. Thesis. Department of Botany, Dhaka University, Dhaka-1000, Bangladesh.

Khan, S.A. 1973. Effect of growth regulators on physiology of soybean (Glycine max (L) Merril.) plants. M.Sc. Thesis, Department of Botany, Dhaka University, Dhaka-1000, Bangladesh.

Khanom, S.A. 1992. Physiological and biochemical studies of growth and yield of mustard (Brassica campestris L. var. Sampad) following potassium naththenate application. M.Sc. Thesis, Department of Botany, Dhaka University, Dhaka-1000, Bangladesh.

Mallik, A.U. and Q.A. Fattah. 1974. Physiology of jute plants. II. Effect of gibberellic acid on the physiology and biochemistry of Atompat 5. Dacca Univ. Stud. B. XXII(1): 53-59.

Maske, V.G., R.D. Deotale, P.N. Sorte, N.D. Tale and C.N. Chore. 1997. Germination, root and shoot studies in soybean as influenced by $\mathrm{GA}_{3}$ and NAA. J. Soils and Crops 72(2): 147-149.

Naidu, N.V., A. Satyanarayana. and P. Seenaiah. 1996. Inter-relationships between yield and yield attributes in cowpea (Vigna unguiculata L. Walp). Ann. Agric. Res. 17(4): 337-341.

Patel, I. and O.P. Saxena. 1994. Screening of PGRs for seed treatment in green gram and black gram. Indian J. Plant Physiol. 27(3): 206-208.

Rao, J.S.P. and A. Narayanan. 1998. Effect of water and light stress and foliar application of auxin on flower abscission and seed yield of pigeon pea. Field Crop Abstract No. 5191.

Siddiqui, S. and H.N. Krishnamoorthy. 1991. Effect of B-nine on nodulation and nitrogen fixation in cowpea (Vigna unguiculata L.) and gram (Cicer arietinum L.) under saline conditions. Haryana Agric. Univ. J. Res. 21: 10-17.

Singh, T., B.V. Singhand and B.S. Panwar. 1972. Effect of pre-sowing treatments with phytohormones on the yield of pea (Pisum sativum). Indian J. Agric. Res. 6(4): 279-284.

Rahman, M.M. 1989. Progress and prospect of minor pulses in Bangladesh. In: Advances in Pulse Research in Bangladesh. pp. 43-50.

Sarker, R.A. 1994. Grain yield and grain protein of cowpea as affected by agronomic management. Ph.D. Thesis. Agronomy Department. Bangladesh Agric. Univ. Mymensingh, Bangladesh.

Saxena, O.P. 1994. Screening of PGRs for seed treatments in green gram and black gram. Indian J. Pl. Physiol. 37(3): 206-208.

Taslima, K. 2003. Effect of indole-3-acetic acid (IAA) on growth, physiological and biochemical responses and yield attributes of cowpea (Vigna unguiculata (L) Walp) var. Barifalon-1. M.Sc. Thesis. Department of Botany, Dhaka University, Dhaka-1000, Bangladesh.

Uddin, M.M., M.A. Quadir, A.R. Choudhury and M.K Choudhury. 1994. Effects of growth regulators on growth and pod yield of lablab bean grown in summer. Ann. Bangladesh Agric. 4(2): 79-85. 